\title{
The Influence of Marketing Strategies on Growth and Sustainability in the Original Equipment Manufacturing Industry
}

\author{
Janet Nanyangwe' ${ }^{1}$, Jackson Phiri $^{2}$ \\ ${ }^{1}$ Graduate School of Business, The University of Zambia, Lusaka, Zambia \\ ${ }^{2}$ Department of Computer Science, School of Natural, The University of Zambia, Lusaka, Zambia \\ Email: janetnanyangwe1217@gmail.com,jackson.phiri@cs.unza.zm
}

How to cite this paper: Nanyangwe, J., \& Phiri, J. (2021). The Influence of Marketing Strategies on Growth and Sustainability in the Original Equipment Manufacturing Industry. Open Journal of Business and Management, 9, 1446-1461.

https://doi.org/10.4236/ojbm.2021.93077

Received: February 10, 2021

Accepted: May 28, 2021

Published: May 31, 2021

Copyright $\odot 2021$ by author(s) and Scientific Research Publishing Inc. This work is licensed under the Creative Commons Attribution International License (CC BY 4.0).

http://creativecommons.org/licenses/by/4.0/

\begin{abstract}
The aim of this study was to assess the influence of marketing strategies on growth and sustainability in the OEM industry in Zambia. Based on Porter's Generic Competitive Business Strategies, the study identified the major bottlenecks in the currently employed marketing strategies and assessed the relationship between Porter's generic strategies in achieving KPI's. A quantitative survey with structured questions was administered through self-completion questionnaires to 40 respondents, representing a $95 \%$ response rate. A descriptive research design was used and a quantitative research strategy used. IBM SPSS was used for correlation analysis, to assess the strength of the relationship between variables. The results indicated that at a $1 \%$ level of significance, the Pearson correlation coefficient of 0.01 and 0.000 at sig. ( 2 -tailed) $<0.01$ indicated that there was a statistically significant relationship between cost strategy and revenue and market share growth. The results further showed Pearson correlation coefficients of 0.000 at sig. (2-tailed) $<0.01$ indicating that there was a statistically significant relationship between differentiation strategy and revenue and market share growth. However, the results indicted a Pearson correlation coefficient of 0.015 and 0.036 which was not statistically significant at sig. (2-tailed) $<0.05$ between focus strategy and revenue and market share growth. According to the research hypotheses testing, cost strategy and differentiation strategy had greater priorities and potential to achieving profitable and sustainable growth in the market.
\end{abstract}

\section{Keywords}

OEM, Influence, Porter's Generic Competitive Strategies, Bottlenecks, KPI’s 


\section{Introduction}

A marketing strategy may be defined as a plan (usually long term) to achieve the organization's objectives (Kotler, 1997). Most research studies explore the performance of a firm consider two key elements, which are revenue growth and market share growth. Porter (2004) stated that successful implementation of strategies leads to superior performance and competitive advantage against competitors. The successful implementation of competitive strategies enables companies to have a distinction from competitors. Later, Porter (2008) further concluded that competitive strategies enabled firms to target new and existing market segments hence improved sales and market share.

The Original Equipment Manufacturing (OEM) industry is facing a global competition challenge; poor sales network management and high supplier and customer deflection have become a challenge to some enterprises. The increase in competition has called for enterprises in this line of business to come up with competitive strategies that will help them sustain their growth profitably. Achim and Borlea (2008) assessed the correlations between performance-profitability-return-growth useful for managerial strategic decisions, which leads companies to global business performances, in the actual context of sustainable development. The rise of a new and exposed world economy, the changes in customer requirements and the universal marketable and profitable network have all increased the interdependency and links of markets around the world. Customer presence, penetration, operational, and service excellence are some of the strategies that were attempted in the past. But in order to stay ahead of competition, OEM's must apply the most efficient and effective competitive strategies.

Competitive strategies are designed to give firms an understanding of the changes in the environment and a view of the opportunities available to the firm and quick response to any barriers arising. Organizations pursue pace keeping by creating better use of their resources with the aim of achieving sustainability and creating the competitive advantage, making them superior to the competing organizations (Alnidawi \& Omran, 2016). Justinian (2015) sites; "strategy researchers argue that the ability of the firm to utilize existing resources and its ability to accumulate new resources more efficiently and effectively relative to competitors enable it to achieve a competitive advantage" as cited in Pimtong, (2009). Kehinde and Ikioda (2011) as cited by Wang'odu stated that the end-result is one of greater efforts for the firm and increased market share leading to more profitability.

Firms are compelled to adopt competitive strategies because of the need to attend to the growing needs of customers for improved satisfaction. As a means of assessing sales and market share, enterprises set up factors of success which enables them monitor their performance in the market in which they operate. Key Performance Indicators (KPI's) are systems that monitor, analyze and measure the success of the firm. Firms have become conscious of the need to not 
only adopt competitive strategies to cope with competition and accommodate changes in the external environment, but also to ensure that the KPI's are achieved through the adopted strategies. This has forced firms in the OEM industry to adjust themselves and accommodate changes in the external environment in order to meet the ever-changing needs of customers. This research assesses the influence of competitive marketing strategies adopted by two OEM's on the Copperbelt on their growth and sustainability. The literature on assessment of competitive marketing strategies is very limited, which makes further research a necessity to gain more insight on competitive strategies.

The organization of the article is as follows; the theoretical background that guided the research will be out lined, thereafter, a review of the literature, followed by the methodology used in the study. In addition, the results of the study and a discussion of the results given and lastly, the conclusions and recommendations drawn from the study.

\section{Literature Review}

A marketing strategy may be defined as a plan (usually long term) to achieve the organization's objectives (Kotler, 1997). Competitive strategies are a broad range of strategies that companies resort to in order to cope with competition, beat competition or keep ahead of competitors (Amit \& Shoemaker, 2003).

\subsection{Porter's Generic Competitive Strategies}

Among the various models of competitive strategies is Michael Porter's generic competitive strategies. He categorized three general types of strategies commonly used by businesses to achieve and maintain competitive advantage. The strategies are cost leadership, differentiation and focus strategy.

According to this model, a company can choose how it wants to compete, based on the match between its type of competitive advantage and the market target pursued, as the key determinants of choice (Akan, Allen, Helms, \& Spralls, 2006). Cost leadership is defined in two types. Type 1 is a low cost strategy that offers products or services to a wide range of customers at the lowest price available to the market. Whereas Type 2 is a best value strategy that offers products or services to a wide range of customers at the best price-value available on the market, it aims to offer customers a range of products or services at the lowest price available compared to a rivals product with similar attributes (Kabeyi, 2018). The goal of cost leadership is to stay ahead of competition by offering lower priced products and services than that of competitors with a view to increase profits. Tanwar (2013) states that a firm, which finds and exploits all sources of cost advantage and aims at becoming a lot cost producer in the industry is said to pursue a sustainable cost leadership strategy. This is achieved by reducing costs while charging industry-standard prices. It can also be achieved by increasing a firm's market share, while maintaining sustainable high profits. Market share may be increased by opting to focus on a market segment that has 
been penetrated the least by competitors, by so doing, the pressure of matching competition is eliminated. David (2011) emphasizes that low cost and best value strategies target a large market. Porter (1998: p. 35) stated this strategy increasingly common in the early 1970s because of generalization of the experience curve concept. A successful cost leadership strategy is likely to rest upon a number of organizational features. Attainment of a position of cost leadership depends upon the arrangement of value chain activities (Evans, Campbell, \& Stonehouse, 2006). The characteristics of low cost are Firm achieves significant proportion of market, economics of scale in procurement, large scale production, use of own sales force, focus on primary products and special sales force for specific product line among others, McGee (2014).

The second generic strategy is differentiation strategy. An enterprise will offer different products or services that create a unique situation. Ideally, companies differentiate themselves in several dimensions. Differentiation strategy does not allow the company to ignore costs, even though these costs are not the main strategic goal (Porter, 1998: p. 38) as cited by (Vahdati et al., 2018). A firm seeking to be unique in its industry along some dimensions of its product or service that are widely valued by customers is said to have adopted differentiation strategy, (Tanwar, 2013). The aim of differentiation is for a firm to offer products and services whose benefit is different from those offered on the market. For this strategy to be implemented successfully, the product or service being offered needs to be significantly better than that of the competitions. This improves the perceived value by the customers and as a result, the profit margins may be enhanced by increasing the price. The best differentiation concentrates on products and services that are hard or too expensive for rivals to imitate (David, 2011). Bordean et al. (2010) A differentiation strategy is based upon persuading customers that a product is superior in some way to that offered by competitors. In differentiation strategies, the emphasis is on creating value through uniqueness, as opposed to lowest cost (Hlavacka, Bacharova, Rusnakova, \& Wagner, 2001; Bauer \& Colgan, 2001; Cross, 1999). Uniqueness is achieved through service innovations, superior service, creative advertising, better supplier relationships leading to better services, or in an almost unlimited number of ways.

McGee (2014) referred to product differentiation as a characteristic of imperfect markets where non-price strategies are important. Product differentiation is the act of making products different from one another. This might involve tangible differences such as quality, reliability, performance, or design. Mitroulis and Kitsios (2016) stated that being competitive is a crucial capability of today's organizations. Successful innovation management appears to be a catalyst in their growth. How could a firm achieve competitive advantage without being competitive? Market orientationis the answer. According to Avlonitis, Papastahopoulou \& Gounaris (2001), customer satisfaction is very important for the firms' actions and strategic moves Moreover, market orientation is always useful due to offer- 
ing information that could help firms be competitive (Salavou, Baltas, \& Lioukas 2004). Customers always seek for benefit. Firm's mission is to make it a long-term dynamic capability. In order to survive, organizations should be able to innovate. This is achieved on by creating dynamic capabilities, on which innovation process could be based (Yang, 2011).

Firms try to wield their best efforts for achieving profits that make possible their survival, the covering of their expenses and the maximization of their values (Kumar, Jones, Venkatesan, \& Leone, 2011; Jime'nez-Jime'nez \& Sanz-Valle, 2011; Salavou et al., 2004; Erdil, Erdil, \& Keskin, 2004). Hence, it is vital that managers identify and understand strategic orsientations, for instance market orientation, to make firms likely to achieve competitive advantage that leads to superior organizational performance. Considering that low unit cost is less important than distinctive product/service features to firms differentiation strategy, the firm's total cost structure is really substantial (Tampoe, 1994).

The final generic strategy is focusing on a particular buyer group, segment of the product line or geographic market. Focus as well as differentiation is done in different forms. If the low cost and differentiation strategies established in the entire industry with the aim of achieving the objectives, then entire focus strategy revolve around achieving a specific goal and each of the functional policies designed with respect to this objective. The focus strategy focuses on this principle that in this way, companies can be reached to their limited strategic goals more effective and more efficient than other competitors can. As a result, the company through better meets the needs of a specific target, achieve to differentiation, reduce costs in providing the services or both Vahdati et al. (2018). Focus means producing products and services that fulfill the needs of small groups of consumers. Tanwar (2013) writes when a firm seeks a narrow competitive scope, selects a segment or a group of segments in the industry and tailors its strategy to serving them to the exclusion of others; the strategy is termed focus strategy. The purpose of this strategy is to provide products or services to a selected market segment. The market segment selected requires a lot of research and an understanding of the customers' requirements. There are two alternative types of focus strategies; Low-cost focus strategy and Best-value focus strategy. Low cost focus strategy offers products or services to a small range of customers called a niche group of customers at the lowest price possible in the market. Best-Value focus strategy offers products or services to a small range of customers at the best price-value available in the market. This is called focused differentiation (Kabeyi, 2018). Bordean et al. (2010) state that a focus strategy aims at a segment of the market for a product rather than at the whole market (Hlavacka et al. 2001; Bauer \& Colgan, 2001; Cross, 1999). Firms pursuing focus strategies have to be able to identify their target market segment and both assess and meet the needs and desires of buyers in that segment better than any other competitor meets. Focus strategies are based on differentiation or lowest cost. There is much debate as to whether or not a company can have a 
differentiation and low-cost leadership strategy at the same time (Helms, Clay, \& Peter, 1997; Harrison \& Enz, 2005) stated that a focus strategy emphasizing the lowest cost is rare as it is hard to please a particular guest segment without some form of differentiation. Figure 1 shows Porters Generic competitive strategies.

\subsection{Empirical Review of Literature}

In a study of Porter's Generic Competitive Strategies by Tanwar (2013), case studies were conducted for each generic competitive strategy. Some firms made an effort to pursue more than one strategy at a time by bringing out a differentiated product at low cost. Tanwar concluded that such approaches were successful in short term; but they are hardly sustainable in the long term. Allen \& Helms (2016), conducted a research; Linking Strategic Practices and Organizational Performance to Porter's Generic Strategies, the findings supported much of the popular literature and discussions about aligning strategic practices consistent with the chosen generic strategy for optimal organizational performance. The study stressed the importance of communication to the employees about the relationship between performance and strategy so they understand the organization's generic strategy as well as the linkages between their lower-level strategic practices and the overall firm performance and ultimately longevity. Akçagün \& Vedat Dal (2014) carried out a research titled, "The Use of M. Porter's Generic Strategies in the Turkish Apparel Industry and Strategy Proposals for Companies". In yet another study by Kinyuira (2014), the research sought to uncover the effects of Porter's Generic Competitive Strategies on the Performance of Savings and Credit Cooperatives (Saccos) in Murang'a County, Kenya. The study showed significant effects of cost leadership, differentiation and focus strategies on performance of Saccos and showed how the company could achieve superior performance. Furthermore, generic strategies were said to be successfully linked to organizational performance using key strategic practices. In a study by Viltard (2017) on Strategic Mistakes (Avoidable): The Topicality of Michael Porter's Generic Strategies, the findings included a list of critical strategic practices significantly associated with organizational performance for each

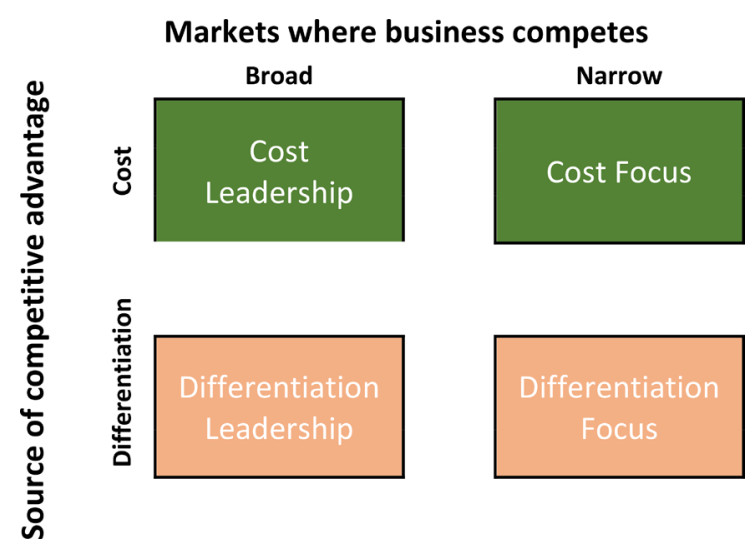

Figure 1. Porters generic competitive strategies. 
of Porter's generic strategies. In a study by Vahdati et al. (2018), Generic Competitive Strategies toward Achieving Sustainable and Dynamic Competitive Advantage, the authors stated that a main method to achieving the competitive advantage is applying generic competitive strategies to be used in a single or collective manner thereby increasing the possible of success of an enterprise in the market. In another study by McGee (2014), titled differentiation strategies, among the authors findings was that different competences were indicated. Cost leadership is usually manufacturing and procurement based, whereas differentiation activity is marketing based.

Olwande (2014) undertook a research on the Application of Porter's Generic Business Strategies and Performance of Pharmaceutical Wholesalers in Kenya. Among the research findings, pursuit of one generic business strategy as suggested by Porter, places a firm in a better strategic position and results in superior performance rather than a situation where the firm is "stuck in the middle".

\section{Research Methodology}

This study followed a descriptive research design. The questionnaires were administered to 42 respondents, of which 40 correctly completed questionnaires were returned which represented a $95 \%$ response rate.

Cochran's Sample Size Formula allowed the calculations of an ideal sample size given a desired level of precision, desired confidence level, and the estimated proportion of the attribute present in the population. Cochran's formula is considered especially appropriate in situations with large populations. A sample of any given size provides more information about a smaller population than a larger one, so there's a "correction" through which the number given by Cochran's formula can be reduced if the whole population is relatively small.

The Cochran formula is:

$$
N_{o}=z^{2} p q / e^{2}
$$

where:

$e$ is the desired level of precision (i.e. the margin of error),

$p$ is the (estimated) proportion of the population which has the attribute in question,

$q$ is $1-p$.

The $z$-value is found in a $Z$ table.

An assumption was made that half of the employees have knowledge about marketing strategies and are either in middle or upper management positions and hence are more or strategic than operational level, So $p=0.5$ or otherwise $50 \%$. Now let's say we want $95 \%$ confidence, and at least 5 percent, plus or minus, precision. A $95 \%$ confidence level gives us $\mathrm{Z}$ values of 1.96 , per the normal tables, so we get 


$$
\left((1.96)^{2}(0.5)(0.5)\right) /(0.05)^{2}=385
$$

So a random sample of 385 employees in the target population should be enough to give us the confidence levels we need. However, there was a modification for the Cochran Formula for Sample Size Calculation in Smaller Populations. Since the population under research is small, we can modify the sample size we calculated in the above formula by using this equation:

Here $n_{0}$ is Cochran's sample size recommendation, $\mathrm{N}$ is the population size, and $\mathrm{n}$ is the new, adjusted sample size. In our earlier example, if there were just 45 employees in the target population, we would calculate

$$
385 /(1+(385 / 45))=40.38461538
$$

Therefore, 40 was the recommended sample size, and hence 42 questionnaires were distributed.

The research strategy used for this study was quantitative.

The sampling method used for this research was probability sampling. The sampling technique used was stratified random sampling. This was done by dividing the main population into a sub population; in this case it was done by dividing the employees according to the departments in which they operate. A semi-structured questionnaire was used to collect primary data from the respondents. The questionnaire comprised 2 sections. The first section was demographic questions; the second were questions on the use of Porters Competitive Marketing Strategies, of which a 5-point Likert scale was used for the variables, which ranged from $1=$ strongly disagree to $5=$ strongly agree. The correlation analysis between Porter's marketing strategy variables and the key performance indicators (KPI's) of growth and sustainability was carried out to assess the strength of the relationships in the hypotheses. Frey (2017) Statistical Package for Social Sciences (SPSS) is a commercially distributed software suitable for data management and statistical analysis. Introduced in 1968, it helped revolutionize research practices in the social sciences, enabling researchers to conduct complex statistical analyses on their own (IBM, 2009). Statistical tests were done at $1 \%$ and $5 \%$ significant level. The results were discussed as per objective.

\section{Conceptual Framework}

The case study recommends a conceptual framework shown in Figure 2;

The below hypotheses were developed;

- H1a: There is a positive relationship between cost leadership competitive strategy and profit.

- H2a: There is a positive relationship between cost leadership competitive strategy and market share.

- H1b: There is a positive relationship between differentiation competitive strategy and profit. 
- H2b: There is a positive relationship between differentiation competitive strategy and market share.

- H1c: There is a positive relationship between focus competitive strategy and profit.

- H2c: There is a positive relationship between focus competitive strategy and market share.

A Pearson correlation was used to determine whether the variables were significantly linearly related. The value of the coefficient ranges from -1 to +1 where the absolute value of the Pearson correlation coefficient signifies the strength of the linear relationship. Thus, a correlation analysis provided information on the strength and direction of the relationship between the variables. Table 1 shows the results of the hypothesis tests.

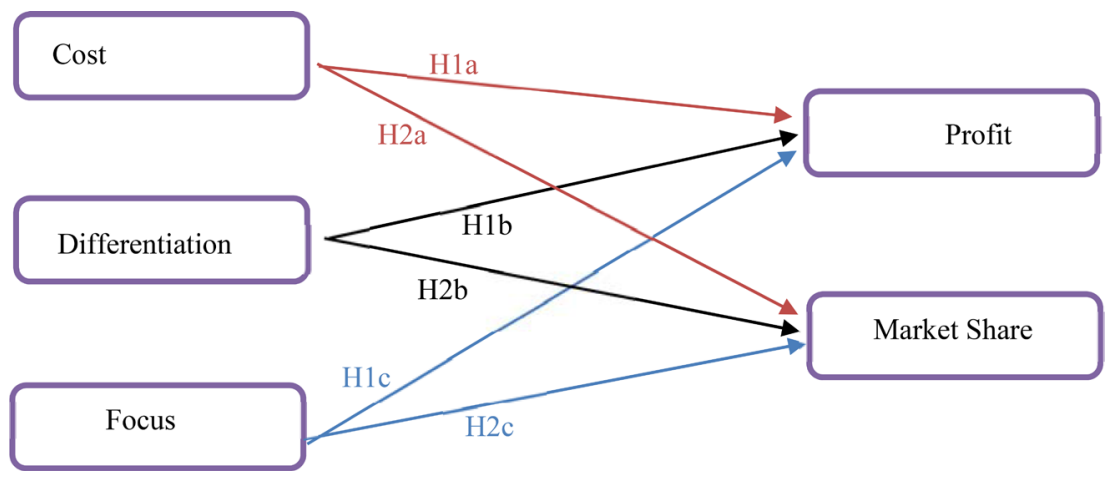

Figure 2. Hypothesis development of the conceptual framework model.

Table 1. Descriptive statistics results.

\begin{tabular}{cccc}
\hline Variable & Description & Frequency & Percentage (\%) \\
\hline \multirow{3}{*}{ Gender } & Female & 9 & 23 \\
& Male & 31 & 77 \\
\hline \multirow{2}{*}{ Age } & $21-30$ & 10 & 25 \\
& $31-40$ & 17 & 42.5 \\
& 41 - 50 & 10 & 25 \\
& 51 and above & 3 & 7.5 \\
Department & Supply and Logistics & 14 & 35 \\
& Service and Maintenance & 8 & 20 \\
& Sales and Marketing & 13 & 32.5 \\
& Finance & 4 & 10 \\
& Other & 1 & 2.5 \\
\hline \multirow{3}{*}{ Length of Service } & Less than 1 year & 3 & 7.5 \\
& 1 - 3 years & 14 & 35 \\
& 4 - 6 years & 1 & 2.5 \\
& 7 - 10 years & 9 & 22.5 \\
& More than 10 years & 13 & 32.5 \\
\hline
\end{tabular}




\section{Results and Discussion}

This section gives the research results of the study from the descriptive and correlation tests that were run based on Porters Generic Competitive Strategies. Data was analyzed using descriptive analysis and Pearson correlation coefficient was used to determine the relationship between the variables.

\subsection{Basic Statistical Analysis}

Two Original Equipment Manufacturing Companies participated in the survey. Forty-two questionnaires were issued out, 40 were completed correctly and returned. The returned questionnaires represented a response rate of $95 \%$, which the study considered adequate for analysis. Out of which 31 of the respondents were male which represented $77 \%$ of the respondents. $42.5 \%$ of the respondents were aged between 31 and 40 years old. The highest number of respondents were from the Supply and Logistics department and the Sales and Marketing department. 35\% of the respondents had served in their respective companies for 1 - 3 years, while $32.5 \%$ had served for over 10 years. Below are the detailed descriptive statistics of the respondents.

\subsection{Hypothesis Analysis}

Six hypotheses were tested using Pearson's correlation, to assess the strength of the relationship between variables.

The results in Table 2 and Table 3 indicated that at a 1\% level of significance,

Table 2. Cost strategy/revenue growth.

\begin{tabular}{cccc}
\hline & Correlations & Cost Strategy & Revenue Growth \\
\hline Pearson Correlation & 1 & $0.499^{* *}$ \\
Sig. (2-tailed) & $\mathrm{N}$ & 40 & 0.001 \\
& Pearson Correlation & 40 \\
Revenue Growth & Sig. (2-tailed) & $0.499^{* *}$ & 1 \\
& $\mathrm{~N}$ & 0.001 & 40 \\
\hline
\end{tabular}

${ }^{* *}$ Correlation is significant at the 0.01 level (2-tailed).

Table 3. Cost Strategy/Market Share Growth.

\begin{tabular}{cccc}
\hline & Correlations & Cost Strategy & Market Share Growth \\
\hline \multirow{2}{*}{ Cost Strategy } & Pearson Correlation & 1 & $0.526^{* *}$ \\
& Sig. (2-tailed) & 40 & 0.000 \\
$\mathrm{~N}$ & Pearson Correlation & $0.526^{* *}$ & 1 \\
\hline \multirow{2}{*}{ Market Share Growth } & Sig. (2-tailed) & 0.000 & \\
& $\mathrm{~N}$ & 40 & 40 \\
\hline
\end{tabular}

${ }^{*}$ Correlation is significant at the 0.01 level (2-tailed). 
the Pearson correlation coefficient of 0.01 and 0.000 respectively at sig. (2-tailed) $<0.01$ indicated that there was a statistical significant relationship between cost, and revenue and market share growth and hence reject the null hypothesis.

Table 4 and Table 5 results further showed Pearson correlation coefficients of 0.000 correspondingly which is statistically significant if the sig. (2-tailed) $<0.01$ indicating that there was a statistical significant relationship between differentiation, and revenue and market share growth and hence the null hypothesis was rejected.

However, the results indicated that there was a relationship between focus strategy, and revenue and market share growth as the results showed a Pearson correlation coefficient of 0.015 and 0.036 in Table 6 and Table 7 separately,

Table 4. Differentiation strategy/revenue growth.

\begin{tabular}{cccc}
\hline & Correlations & Differentiation Strategy & Revenue Growth \\
\hline & Pearson Correlation & 1 & $0.602^{\star *}$ \\
Differentiation Strategy & Sig. (2-tailed) & & 0.000 \\
& $\mathrm{~N}$ & 40 & 40 \\
\hline Revenue Growth & Pearson Correlation & $0.602^{* *}$ & 1 \\
& Sig. (2-tailed) & 0.000 & 40 \\
\hline
\end{tabular}

${ }^{* *}$ Correlation is significant at the 0.01 level (2-tailed).

Table 5. Differentiation strategy/market share growth.

\begin{tabular}{|c|c|c|c|}
\hline & Correlations & Differentiation Strategy & Market Share Growth \\
\hline \multirow{3}{*}{ Differentiation Strategy } & Pearson Correlation & 1 & $0.602^{\star *}$ \\
\hline & Sig. (2-tailed) & & 0.000 \\
\hline & $\mathrm{N}$ & 40 & 40 \\
\hline \multirow{3}{*}{ Market Share Growth } & Pearson Correlation & $0.602^{\star *}$ & 1 \\
\hline & Sig. (2-tailed) & 0.000 & \\
\hline & $\mathrm{N}$ & 40 & 40 \\
\hline
\end{tabular}

${ }^{* *}$ Correlation is significant at the 0.01 level (2-tailed).

Table 6. Focus strategy/revenue growth.

\begin{tabular}{cccc}
\hline & Correlations & Focus Strategy & Revenue Growth \\
\hline \multirow{2}{*}{ Focus Strategy } & Pearson Correlation & 1 & $0.384^{*}$ \\
& Sig. (2-tailed) & 40 & 0.015 \\
$\mathrm{~N}$ & Pearson Correlation & $0.384^{*}$ & 1 \\
\hline \multirow{2}{*}{ Revenue Growth } & Sig. (2-tailed) & 0.015 & 40 \\
& $\mathrm{~N}$ & 40 & 40 \\
\hline
\end{tabular}

${ }^{\star}$ Correlation is significant at the 0.05 level (2-tailed). 
Table 7. Focus strategy/market share growth.

\begin{tabular}{cccc}
\hline & Correlations & Focus Strategy & Market Share Growth \\
\hline \multirow{3}{*}{ Focus Strategy } & Pearson Correlation & 1 & $0.332^{\star}$ \\
& Sig. (2-tailed) & & 0.036 \\
& $\mathrm{~N}$ & 40 & 40 \\
\hline \multirow{3}{*}{ Market Share Growth } & Pearson Correlation & $0.332^{*}$ & 1 \\
& Sig. (2-tailed) & 0.036 & 40 \\
\hline
\end{tabular}

Table 8. Summary of hypothesis results.

\begin{tabular}{|c|c|c|c|}
\hline $\begin{array}{l}\text { Number of } \\
\text { Hypothesis }\end{array}$ & Hypothesis Statement & $\begin{array}{c}\text { Decision Rule } \\
\mathrm{P}<0 \text { (Significant) or } \\
>0 \text { (Not Significant) }\end{array}$ & Results \\
\hline H1a & $\begin{array}{l}\text { There is a positive relationship between cost } \\
\text { leadership competitive strategy and profit }\end{array}$ & $\begin{array}{c}0.001<0.01 \\
\text { Significant }\end{array}$ & Accepted \\
\hline $\mathrm{H} 2 \mathrm{a}$ & $\begin{array}{l}\text { There is a positive relationship between cost } \\
\text { leadership competitive strategy and market share. }\end{array}$ & $\begin{array}{c}0.000<0.01 \\
\text { Significant }\end{array}$ & Accepted \\
\hline $\mathrm{H} 1 \mathrm{~b}$ & $\begin{array}{l}\text { There is a positive relationship between } \\
\text { differentiation competitive strategy and profit }\end{array}$ & $\begin{array}{c}0.000<0.01 \\
\text { Significant }\end{array}$ & Accepted \\
\hline $\mathrm{H} 2 \mathrm{~b}$ & $\begin{array}{l}\text { There is a positive relationship between } \\
\text { differentiation competitive strategy and market share }\end{array}$ & $\begin{array}{c}0.000<0.01 \\
\text { Significant }\end{array}$ & Accepted \\
\hline $\mathrm{H} 1 \mathrm{c}$ & $\begin{array}{l}\text { There is a positive relationship between focus } \\
\text { competitive strategy and profit }\end{array}$ & $\begin{array}{c}0.015>0.01 \\
\text { Not Significant }\end{array}$ & Rejected \\
\hline $\mathrm{H} 2 \mathrm{c}$ & $\begin{array}{l}\text { There is a positive relationship between focus } \\
\text { competitive strategy and market share. }\end{array}$ & $\begin{array}{c}0.036>0.01 \\
\text { Not Significant }\end{array}$ & Rejected \\
\hline
\end{tabular}

which was not statistically significant at sig. (2-tailed) $<0.05$, and therefore fail to reject the null hypothesis. Table 8 shows the summary of the hypothesis results.

\section{Conclusion and Recommendations}

The findings showed that large differentiation strategy and cost strategy were the main strategies used by the OEM's that took part in this study. The organizational performance was gauged against revenue growth and market share growth and the correlation results showed that cost and differentiation strategy had greater priorities and had an appropriate potential to achieving profitable and sustainable growth in the market. Therefore, according to the results of the research hypotheses testing, it is inference that among the marketing strategies, differentiation strategy was the most used competitive strategy. There is greater need therefore for OEM's to elevate their products and services to accomplish revenue growth and market share growth. Currently, focus strategy is used the least hence it has been labeled as a strategy that does not promote revenue growth or market share growth. Further, more growth strategically inclined ef- 
forts must be made towards differentiation strategy since it has been viewed to have greater priorities and has an appropriate potential to achieving profitable and sustainable growth in the dynamic market.

It was therefore recommended that managers in strategic roles need to put more emphasis on the cost and differentiation competitive strategies as tools to compete in the market. It was also recommended that OEM's should clearly communicate to their employees, especially those that are new to the organization on the relationship between performance and strategy so they understand the organization's generic strategy as well as the linkages between their lower-level strategic practices and the overall firm performance and ultimately longevity. Lastly, further research to establish factors that lead to change in firms' competitive strategies within the OEM industry in Zambia was recommended.

\subsection{Limitations}

The biggest limitation of the study was the use of quantitative methods unaccompanied by qualitative methods in collecting data. Qualitative methods of collecting data in this research would have come from open-ended questions, which would have collected data in a different way, instead of providing questions with only specific answers, comparable to a poll, qualitative research sanctions people to be themselves during the research process. In turn, methodologies would have been investigated with greater accuracy. In the case of Original Equipment manufacturers, customer patterns can often change. The processes, which are provided by qualitative research, provide for a hypothetical understanding as to why attitudes may shift either from cost based or differentiation based or focus based strategy. This may even lead to a definitive explanation, which can allow the business to adapt to the perspective shift. Because qualitative research helps us all understand attitudes better, it becomes easier to maintain customer relationships. Detailed open-ended questions would have attained far-reaching information with regards to variables of marketing strategies and OEM KPI's. Secondly, the study targeted two OEM enterprises on the Copperbelt province; it did look at other provinces in Zambia where geographic factors would have been considered to have an effect on the OEM's performance.

\subsection{Proposed Future Work}

The study was among the few of this kind to focus on the influence of marketing strategies on the performance of the Original Equipment Manufacturing Industry. Research identified that not many researchers delved into their impact on a firm's performance and the achievement of Key Performance Indicators (KPI's). Most studies did not highlight the impact of the applied strategy on the performance of the business. This study attempted to address this gap in literature. Further research may be extended to different enterprises in the OEM industry to supplement the findings of this research and help streamline future competitive strategies. The future studies may also look to target a larger sample of em- 
ployees.

\section{Acknowledgements}

The authors would like to acknowledge the valuable contribution from the participants of the survey, and the research supervisor for his relentless dedication.

\section{Conflicts of Interest}

The authors declare no conflicts of interest regarding the publication of this paper.

\section{References}

Achim, M., \& Borlea, S. (2008). Business Performances: Between Profitability, Return and Growth. Annals of University of Craiova-Economic Sciences Series, 2, 1-12.

Akan, O., Allen, R. S., Helms, M. M., \& Spralls, S. A. (2006). Critical Tactics for Implementing Porter's Generic Strategies. Journal of Business Strategy, 27, 43-53. https://doi.org/10.1108/02756660610640173

Akçagün, E., \& Dal, V. (2014). The Use of M. Porter's Generic Strategies in The Turkish Apparel Industry and Strategy Proposals for Companies. Tekstil ve Konfeksiyon, 24, 151-157.

Allen, S. R., \& Helms, M. M. (2006). Linking Strategic Practices and Organizational Performance to Porter's Generic Strategies. Business Process Management Journal, 12, 433-454. https://doi.org/10.1108/14637150610678069

Alnidawi, A. B., \& Omran, M. F. (2016). Human Resources Management Activities Adopted in the Value Chain Model and their Impact on the Organizational Sustainability-An Empirical Study in the Jordanian Pharmaceutical Companies. International Business Research, 9, 106-117. https://doi.org/10.5539/ibr.v9n8p106

Amit, R., \& Shoemaker, P. J. (2003). Strategic Assets and Organizational Rent. Strategic Management Journal, 14, 33-46. https://doi.org/10.1002/smj.4250140105

Avlonitis, G., Papastahopoulou, P., \& Gounaris, S. (2001). An Empirically-Based Typology of Product Innovativeness for New Financial Services: Success and Failure Scenarios. Journal of Innovation Management, 18, 324-342.

https://doi.org/10.1111/1540-5885.1850324

Bauer. C., \& Colgan. J., (2001). Planning for electronic Commerce Strategy: An Explanatory Study from the Financial Services Sector. Logistics Information Management, 14, 24-32. https://doi.org/10.1108/09576050110360205

Bordean, O., Borza, A., Razvan, N., \& Crisan-Mitra, C. (2010). The Use of Michael Porter's Generic Strategies in the Romanian Hotel Industry. International Journal of Trade, Economics and Finance, 1, 173-178. https://doi.org/10.7763/IJTEF.2010.V1.31 https://www.researchgate.net/publication/288913744 The Use of Michael Porter\%27 s Generic Strategies in the Romanian Hotel Industry

Cross, L. (1999). Strategy Drives Marketing Success. Graphic Arts Monthly, 71, 96-106.

David, F. R. (2011). Strategic Management Concepts and Cases. Upper Saddle River, New Jersey: Prentice Hall.

Erdil, S., Erdil, O., \& Keskin, H. (2004). The Relationships between Market Orientation, Firm Innovativeness and Innovation Performance. Journal of Global Business and Technology, 1, 1-11. 
Evans, N. D., \& Campbell, G. (2006). Stonehouse, Strategic Management for Travel and Tourism. Oxford: Butterworth-Heineman.

Frey, F. (2017). SPSS (Software). https://www.researchgate.net/publication/311101660 SPSS software

Harrison, J. S., \& Enz, C. A. (2005). Hospitality Strategic Management-Concepts and Cases. Hoboken, NJ: John Wiley and Sons.

Helms, M. M., Clay, D., \& Peter, W. (1997). Competitive Strategies and Business Performance: Evidence from the Adhesives and Sealants Industry. Management Decision, 35, 689-703. https://doi.org/10.1108/00251749710186531

Hlavacka, S., Bacharova, L., Rusnakova, V., \& Wagner, R. (2001). Performance Implications of Porter's Generic Strategies in Slovak Hospitals. Journal of Management in Medicine, 15, 44-66. https://doi.org/10.1108/02689230110386489

IBM (International Business Machines Corporation) (2009). IBM Completes Acquisition of SPSS Inc. http://www-03.ibm.com/press/us/en/pressrelease/28522.wss

Jime'nez-Jime'nez, D., \& Sanz-Valle, R. (2011). Innovation, Organizational Learning, and Performance. Journal of Business Research, 64, 408-417.

Justinian, J. M. (2015). Application of Porter's Generic Competitive Business Strategies and Their Effect on Performance in Zanzibar Hotel Industy. Masters Dissertation, Dar es Salaam: Open University Of Tanzania.

Kabeyi, M. (2018). Michael Porter's Five Competitive Forces and Generic Strategies, Market Segmentation Strategy and Case Study of Competition in Global Smartphone Manufacturing Industry. International Journal of Applied Research, 4, 39-45. https://doi.org/10.22271/allresearch.2018.v4.i10a.5275

Kehinde, J. O., \& Ikioda, E. I. (2011). Competitive Marketing Strategies: Tools for Enhancing Value in the Dynamic World of Business. Manager, 13, 50-63.

Kinyuira, D. (2014). Effects of Porter's Generic Competitive Strategies on the Performance of Savings and Credit Cooperatives (Saccos) in Murang'a County, Kenya. Journal of Business and Management, 16, 93-105. https://doi.org/10.9790/487X-166193105

Kotler, P. (1997) Marketing Management: Analysis, Planning, Implementation, and Control (9th ed.). Upper Saddle River, NJ: Prentice Hall.

Kumar, V., Jones, E., Venkatesan, R., \& Leone, R. P. (2011). Is Market Orientation a Source of Sustainable Competitive Advantage or Simply the Cost of Competing? Journal of Marketing, 75, 16-30.

McGee, J. (2014). Differentiation Strategies. In C. L. Cooper, J. McGee, \& T. Sammut-Bonnici (Eds.,), Wiley Encyclopedia of Management (3rd ed., Vol. 3, pp. 3). Hoboken, NJ: John Wiley \& Sons. https://doi.org/10.1002/9781118785317.weom120098 https://www.researchgate.net/publication/280246508 differentiation strategies

Mitroulis, D., \& Kitsios, F. (2016). Fostering a Competitive Differentiation Strategy for Sustainable Organizational Performance. In E. Grigoroudis, \& M. Doumpos (Eds.), Operational Research in Business and Economics (pp. 85-112). Cham: Springer. https://doi.org/10.1007/978-3-319-33003-7 5

https://www.researchgate.net/publication/305726318 Fostering a Competitive Differ entiation Strategy for Sustainable Organizational Performance

Olwande. P. (2014). The Application of Porter's Generic Business Strategies and Performance of Pharmaceutical Wholesalers in Kenya. Thesis, Nairobi: School of business, University of Nairobi.

Pimtong, T. (2009). The Impact of Industry Forces on Resource Competitive Strategies 
and Hotel Performance. Master's Thesis, Stillwater, OK: Oklahoma State University. (Unpublished)

Porter, M. E. (1998). Competitive Strategy: Techniques for Analyzing Industries and Competitors (1st ed., pp. 68-69). New York: Free Press.

Porter, M. E. (2004). The Five Competing Forces That Shape Strategy. Harvard Business Review, 1, 78-93.

Salavou, H., Baltas. G., \& Lioukas. S. (2004). Organizational Innovation in SMEs: The Importance of Strategic Orientation and Competitive Structure. European Journal of Marketing, 38, 1091-1112. https://doi.org/10.1108/03090560410548889

Tampoe, M. (1994). Exploiting the Core Competences of Your Organization. International Journal of Strategic Management Long Range Planning, 27, 66-77. https://doi.org/10.1016/0024-6301(94)90057-4

Tanwar, R. (2013). Porter's Generic Competitive Strategies. IOSR Journal of Business and Management, 15, 11-17.

Vahdati, H., Nejad, S. H., \& Shahsiah, N. (2018). Generic Competitive Strategies toward Achieving Sustainable and Dynamic Competitive Advantage.

https://www.semanticscholar.org/paper/Generic-Competitive-Strategies-toward-Achie ving-and-Vahdati-Nejad/6afdde45ff3b4caac9691c421c8f48c4826ed32e

Viltard, A. L (2017). Strategic Mistakes (Avoidable): The Topicality of Michael Porter's Generic Strategies. Independent Journal of Management \& Production, 8, 474-497. https://www.researchgate.net/publication/317292877 Strategic mistakes AVOIDABL E The topicality of Michel Porter\%27s generic strategies

Wang'odu, A. (2016). Marketing Strategies and Customer Satisfaction: A Case Study of The Institute of Executive Coaches-East Africa. Master's Dissertation, Nairobi: United States International University-Africa.

Yang, J. (2011). Innovation Capability and Corporate Growth: An Empirical Investigation in China. Journal of Engineering and Technology Management, 29, 34-46.

https://doi.org/10.1016/j.jengtecman.2011.09.004 